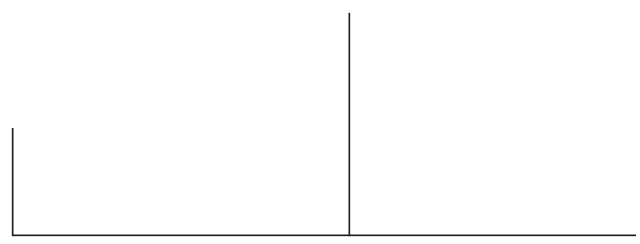

\title{
A trajetória de um autista e suas implicações com a temporalidade
}

\author{
Marília Amaro da Silveira Modesto Santos
}

Este trabalho se propõe a relatar a longa trajetória de um menino autista, no que diz respeito ao estabelecimento da noção de tempo.

Usando referenciais teóricos winnicottianos, procuro mostrar como o autismo é a evidência de um "não tempo", de um processo que estagnou para se proteger de vivências terroríficas, vazias de qualquer sentido de significado.

Utilizando histórias que funcionaram durante muito tempo e de várias formas como o único elo de ligação entre nós, Lucas passa da utilização do ritmo (meu ritmo de leitura) a uma utilização do conteúdo para estabelecer dentro de si o tempo. Tempo de processo, tempo de mudança, tempo de vida.

A sua posição diante da vida, muda. Lucas revela interesse pelo seu ambiente. Depende muito de minha adaptação e da minha habilidade para compreendê-lo e dar sentido ao que viver, agora. Num tempo de descobrimento. 


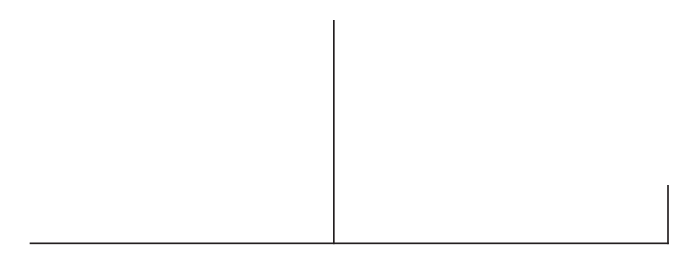

\section{Introdução}

A história do ano

Era mês de janeiro. A nevasca desabava, impetuosa.

[...]

Dir-se-ia que todas as criaturas se achavam dominadas por uma pressa incontida: os homens andavam correndo; precipitavam-se nos braços uns dos outros, segurando-se mutuamente por um instante, para firmar o pé.

$[\ldots]$

Nenhum queria ceder o passo, entrando na neve funda para dar passagem ao outro. E ali ficavam, imóveis e silenciosos, até que por um acordo tácito cada um resolvia sacrificar uma única perna, afundando-a no montão de neve.

\section{$[\ldots]$}

A camada de neve superior estava enfim tão forte, pela madrugada, que podia resistir ao peso dos pardais, os quais desciam, aos pulinhos, para as baixadas, de onde a neve fora removida.

\section{[...]}

- Pio, pio! - disse um. Isto é então um ano novo? Pois olha, é pior que o velho! A gente podia bem ter ficado com aquele. 


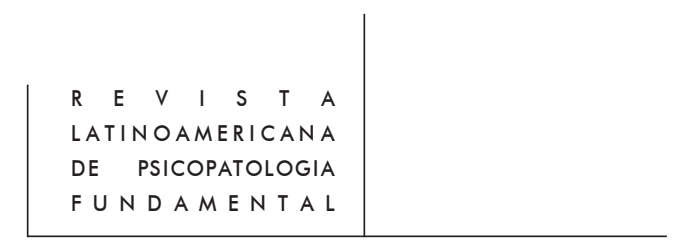

$[\ldots]$

Não estou gostando nada deste!

- É, é isso mesmo; os homens saíram a correr pelas ruas, saudando o ano novo com salvas de tiros - acudiu um pardalzinho que tremia de frio. Atiraram potes às portas e pareciam doidos de alegria, só porque desaparecerá $o$ ano velho. E eu também fiquei muito contente, porque esperava que viriam dias melhores. Mas qual: o frio é até pior que antes. Os homens andam enganados na cronologia.

-É mesmo - disse o terceiro, um pardal já velho, de cabeça branca. Eles lá têm um coisa a que chamam calendário, uma invenção lá deles, e querem que tudo se subordine àquilo. Ora qual! O ano começa quando chega a primavera! É assim na Natureza e eu me guio é por ela.

- Mas ... e quando é que vem a primavera? - indagaram os outros.

- Ora, ela vem quando volta a cegonha. Mas é que ela não tem tempo bem certo para chegar,

- Pio, pio! Quando virá a primavera? Ainda tardará muito? Muito tempo? Muito tempo?

- Muito tempo! - respondeu uma voz, vinda da colina mais próxima, coberta de neve.

A voz foi ecoar ao longe, pelo campo afora. Talvez fosse somente o eco; mas talvez fosse a voz de um velho esquisito, que, no meio da tempestade, estava sentado lá em cima, sobre um montão de neve. Era todo branco.

[...]

Os alvos cabelos eram muito compridos; o rosto pálido, os olhos grandes e claros.

- Quem é aquele velho? - perguntaram os pardais. E um corvo velho, que pousara em um moirão da cerca, tão condescendente que reconhecia que todos nós somos apenas passarinhos aos olhos de Deus, dignou-se responder aos pardais:

- Eu sei; é o inverno, o velho do ano passado. Não morreu, ainda que o afirme o calendário

[...]

- Estão vendo? Pois não foi o que eu disse mesmo? - disse logo o pardalzinho menor. - O calendário é apenas uma invenção humana: não corresponde à Natureza.

[...]

Mas de repente um raio de sol deslizou pela superfície.

[...]

- Pio - pio - pio - pio! Virá já a primavera? Virá já?

$[\ldots]$ 


\section{ARTIGOS}

Já vinham voando, das bandas do sul, as primeiras cegonhas: traziam às costas duas graciosas criancinhas - um menino e uma menina, que atiravam beijos para a Terra. Onde quer que pusessem o pé, brotavam da neve flores alvíssimas.

— Isto sim! - diziam os pardais. — Isto é que se pode chamar de Ano Novo!

[...]

Passaram-se dias, passaram-se semanas. O calor parecia descer em catadupas.

$[\ldots]$

Os mosquitos dançavam no ar, e lá fora, sobre uma pedra, em meio das águas salgadas do mar, fustigadas pelo vento, estava sentado o verão; era um moço robusto, de membros vigorosos, e tinha o cabelo a gotejar água. Remoçando no banho refrescante, ali estava, sob os raios quentes dos sol. Toda a natureza rejuvenescera; tudo se erguia agora, viçoso, forte, belo. Era verão, verão! O agradável e quente verão!

[...]

E de novo passavam os dias e passavam as semanas [...]

As folhas da mata iam ficando cada vez mais amarelas e caindo umas sobre as outras. Desencadeavam-se as tempestades do outono. Já avançara muito o ano, e sobre o leito de folhas amarelas repousava a rainha, fitando com o olhar suave uma estrela cintilante.

\section{$[\ldots]$}

Soprou uma rajada de vento que ergueu as folhas em turbilhão; e quando caíram, aos montões, a rainha sumiu-se.

$[\ldots]$

E chegaram as neves úmidas. Soprava agora um vento gelado. As noites escuras e compridas, sucediam-se em procissão. O rei do ano lá estava, com a cabeleira branca como a neve;

[...]

E os sinos repicaram, saudando a época do Natal.

[...]

E de novo chegaram da cidade os pardais, a perguntar: - Quando virá a primavera? Quando virá a primavera?

$[\ldots]$

Pensando, em silêncio, o inverno acenou para o mato desfolhado e negro, onde cada árvore mostrava bem a forma e a curva dos galhos nus.

[...]

Ao romper do dia a floresta inteira resplandecia, coberta de geada rutilante: era o sonho do verão, sonhado pelo inverno.

[...] 
R $E$ V I I S T

LATINOAMERICANA

DE PSICOPATOLOGIA

FUND A M EN T A L

E os pardais perguntavam:

- Quando virá a primavera?

E, como um eco, das altas colinas cobertas de neve, veio um som:

- Primavera!

[...]

Lá pelas alturas singrava a primeira cegonha; e logo a segunda. E cada uma trazia às costas uma criança encantadora. As cegonhas desceram sobre os campos.

$[\ldots]$

E estava acabada a história do ano.

- Sim! - disseram os pardais. É muito bonita. Mas esta história não está de acordo com o calendário; portanto, não vale nada.

(Andersen, 1961, pp. 243-255)

\section{A história que aconteceu num tempo que não foi}

Era mês de dezembro. Lucas e eu estávamos às portas de nossas férias de verão. Entramos na sala e Lucas não dizia uma palavra. Passamos um tempo em silêncio até que Lucas me pediu para contar uma história. Peguei de cima de minha mesa um dos volumes dos Contos de Andersen. Escolhi aleatoriamente contar-lhe a "História do Ano". Lucas escutou atentamente (o que não era seu costume).

Pediu para que eu repetisse a história várias vezes. Eu ia lhe contando, como era sua vontade, e assim se passou essa sessão. Na época entendia o seu pedido como uma tentativa de elaborar nossa separação no período de férias, já que a história falava sobre o ciclo do tempo.

Quando nos reencontramos, a primeira coisa que Lucas perguntou foi sobre a "História do Ano". Ele mesmo contou o que lembrava da história e, em seguida, pediu-me para que eu a contasse novamente. Seus olhinhos brilhavam...

Isso marca o início da noção de tempo e eu vou contar nossa trajetória até aqui.

\section{Encaminhamento}

Lucas veio a mim através de uma fonoaudióloga que trabalhava com ele havia seis meses, sem obter nenhum resultado. O motivo do trabalho da fono é que Lucas não falava nenhuma palavra. Na verdade, nenhum som saía de sua boca, apesar de já estar com quase três anos de idade. E quando falo nenhum som, refiro-me inclusive a riso e choro. 


\section{ARTIGOS}

Ele não possuía nenhum recurso para se relacionar com pessoas. Ensimesmado, brincava sozinho, sentado no chão, movimentando seu corpo para frente e para trás, ao mesmo tempo que rodava uma pequena bola de isopor que tinha em sua caixa lúdica, fazendo dela um pião.

A visão e o contato com o outro parecia causar-lhe dor. Na iminência de um contato, ele afastava-se, ou virava-se de costas para a pessoa. Seu olhar era evasivo.

Em abril de 1990, iniciei meu trabalho com Lucas, que, na época, tinha dois anos e dez meses. Lucas sofria de autismo.

Foi-lhe recomendado um tratamento com freqüência de quatro sessões semanais (ludoterapia), e terapia para a mãe. Nenhuma das duas recomendações foi possível. Eles dependiam da ajuda de um convênio que concedeu três sessões semanais à criança e nenhuma à mãe. Ela, por sua vez, não se sentia em condições de pagar sozinha sua terapia.

\section{História}

A história familiar de Lucas é muito penosa. Ele é filho de mãe solteira. Sua mãe caiu em grave depressão, após seu nascimento, o que a fez passar de cama os quatro meses de licença pós-parto.

Nesse tempo, a mãe conta que Lucas passava todo o tempo no berço. Uma empregada cuidava estritamente de sua higiene e alimentação.

Quando Lígia, sua mãe, voltou a trabalhar, essa mesma empregada continuou a tomar conta de Lucas até que ele completasse dois anos, quando ela precisou sair do emprego. Foi nessa época que a mãe começou a suspeitar de que havia algo errado com o menino, mas atribuiu o desajuste à saída da empregada.

$\mathrm{O}$ pai de Lucas é marinheiro, primo de sua mãe. Os dois moravam em Belém. Lígia perdeu o pai muito cedo (7 anos). Após a morte do pai, Lígia viveu com a mãe e a irmã mais nova. Ela e a mãe trabalhavam para ajudar na educação da irmã, que acabou vindo para São Paulo onde constituiu família. Lígia cuidou da mãe até ela morrer. Nessa época, ela tinha 18 anos. Após a morte da mãe, ela veio para São Paulo e começou a trabalhar como secretária numa firma de adubos. Sentia-se muito só e, numa visita do seu primo, quando ele estava em terra, tiveram um breve romance. Lígia tinha aproximadamente quarenta anos. Após o nascimento de Lucas, seu pai foi paulatinamente se afastando, até se dar um completo abandono.

Lígia conta como se sentiu sozinha e com medo da responsabilidade. Não se sentia protegida. Nas palavras dela, "sentia-me perdida com o bebê".

Quando Lucas veio para mim, ele freqüentava uma pré-escola que não tinha recursos para compreendê-lo. Sua professora dizia que ele era irônico e não 
$\begin{array}{lllllll}R & E & V & \text { I } & S & T & A\end{array}$

LATINOAMERICANA

DE PSICOPATOLOGIA

FUND A M EN T A L

respondia quando ela lhe falava, para fazer desaforo. Com a orientação de outra psicóloga do mesmo convênio do qual eu fazia parte, ele mudou de escola. E também não deu certo. Nessa, os profissionais já tinham mais recursos para compreendê-lo, mas a escola não tinha uma estrutura para abrigar crianças doentes. Ambas eram escolas para crianças normais. Existia, na época, por parte das psicólogas do convênio, uma crença de que crianças doentes em ambientes saudáveis ficariam boas. Eu não achava que elas estavam totalmente erradas, só que Lucas precisava de uma atenção especial que essas instituições não tinham condições de oferecer. Então, Lucas foi por mim encaminhado para uma instituição especializada em crianças autistas. Essa instituição colaborou muito para o seu desenvolvimento, principalmente na área cognitiva. Lá, Lucas pôde aprender a ler, escrever e fazer contas. Até que chegou um momento que o seu desenvolvimento o obrigou a sair dessa escola. Lucas foi, por essa mesma instituição, encaminhado para outra escola especializada em crianças mentalmente doentes, mas com distúrbios mais leves. Lucas encontra-se lá até hoje e essa escola tem contribuído muito para o seu crescimento.

Algumas considerações teóricas

A psicanálise, de uma maneira ou de outra, realça a importância do investimento materno nos "primeiros tempos" de uma criança, ou, poderíamos até dizer, nos primeiros tempos daquele que ainda não é, para que possa se tornar um ser.

Segundo Tustin (1990), a depressão que uma criança possa vir a detectar em sua mãe pode servir para que ela destrua seu ego a fim de não prejudicar ainda mais sua mãe deprimida, o que resulta numa autonomia autista ilusória. E, nesse contexto, a criança se mostra encapsulada e desinteressada de tudo o que há em seu redor. Desta maneira, a criança não apresenta nenhum objetivo nem identidade. Habita um mundo vazio e sem tempo. Carece de empatia, de imaginação, de vida interior.

O que ocorre com crianças com essa patologia é que uma experiência traumática, como a falta de investimento materno, ocorreu antes de que a mãe nutriz, e tudo que isto implica, tivesse se tornado uma experiência psíquica bem estabelecida e antes de que um senso seguro de constituição do ser pudesse ter se desenvolvido. De acordo com Winnicott, uma mãe, num ambiente tranqüilo, entra em tão grande sintonia com seu bebê que acaba funcionando como o self dele, permitindo que os rituais de alimentação, troca de fraldas, acalmar, brincar e dormir, se dêem de acordo com a vontade do bebê. Todos esses cuidados, não só oferecem gratificações libidinosas ao bebê, como também o preparam para ficar de pé, engatinhar, andar, falar... (cf. Bollas, 1992) 


\section{ARTIGOS}

Se esses rituais não acontecem de maneira satisfatória, o ser não chega a constituir-se, portanto, não é possível também se formar o senso de continuidade do ser. Se não há um ser, não pode haver continuação dele. O que não é, no sentido de existência, não continua. E o continuar implica a existência de um tempo. Portanto, esses pacientes são perseguidos por medos de se desintegrarem, de "caírem infinitamente" num buraco negro, sem fundo, de perder a linha de continuidade que garante suas existências. E assim, o autista fica imobilizado no tempo, protegido do medo de ser morto. E ele fica congelado. Retira-se da vida para proteger a própria vida. Podemos comparar esse estado, segundo Tustin (1990), ao que os egípcios faziam quando mumificavam os corpos para preservarem a continuidade física, para evitar o seu término e a separação da morte. Só que essa mumificação faz com que a criança se sinta presa numa rua sem saída, com horrores primitivos ocultos nas sombras.

Segundo a mesma autora, para crianças autistas, os eventos não têm nenhum movimento. Eles são capturados como pinturas. Assim, a criança vive de forma física. Um objeto autista é uma sensação física. Esses pacientes sofreram precocemente a percepção de que o seio não faz parte da boca. A ilusão da fusão não pôde ser vivida o necessário. A desilusão prematura ocasiona oportunidades insuficientes para a sensação de fusão. Ao invés da criação de ilusões, a criança começa a manipular objetos autistas de forma excessiva, o que a impede de fantasiar, bem como de desenvolver todas as funções do ego.

Como resultado, essas crianças apresentam grande necessidade de isolarse, não conseguem usufruir da linguagem nem mesmo para expressar necessidades e utilizam-se da mesmice como tentativa de fusão com o objeto sendo esta a única maneira deles sentirem-se vivos.

Essas crianças aderem-se rigidamente ao que chamamos de objetos autistas para cortar o vínculo com qualquer ser vivo do mundo real. Por exemplo, eu notava, no início do meu trabalho com Lucas, que eu podia entrar ou sair da sala onde estávamos que isso não fazia nenhuma diferença para ele. O importante para ele era continuar no seu movimento autístico (balançando o seu corpo para frente e para trás), mantendo os seus olhos presos na bola de isopor que rodava como pião.

\section{Um pouco de etiologia}

Quanto à origem do autismo, existem muitas controvérsias. Acho importante ressaltar que não estou querendo aqui colocar as patologias da mãenutriz como causa única desta doença.

Segundo os organicistas, fatores inatos podem contribuir para o surgimento do autismo, mas o meu interesse é poder discutir um pouco sobre as várias 
$\begin{array}{lllllll}R & E & V & \text { I } & S & T & A\end{array}$

LATINOAMERICANA

DE PSICOPATOLOGIA

F U N D A MENT A L

maneiras de podermos ajudar as diferentes crianças autistas a saírem de suas "conchas protetoras" e terem uma vida o mais saudável possível.

Eu não teria tido nenhum êxito nesse trabalho se não fosse a ajuda da Lígia, trazendo Lucas às sessões e aceitando orientações, apesar de todas as suas dificuldades.

Anne Alvarez em seu livro Companhia viva relata o quão difícil deve ser para uma mãe, com tendências depressivas, cuidar de um bebê inatamente pouco responsivo.

Portanto, seguindo os sucessos nos tratamentos de autistas relatados na literatura psicanalítica, acreditei na etiologia desta síndrome como uma interação de fatores inatos com o ambiente, como se os dois se entrelaçassem como duas espirais, tendo como resultado um ser "não ser", um humano "inumano".

\section{Um pouco das dificuldades na trajetória}

Muitas foram as dificuldades com as quais venho me deparando até hoje. Além da gravidade da doença, enfrento os problemas sociais e econômicos que saem da minha alçada, deixando-me impotente.

Lígia, já há algum tempo aposentada, "parada no tempo", não consegue até hoje procurar um outro emprego para ajudar no tratamento do filho ou mesmo para fazer sua terapia. Além do convênio não pagar terapia para ela, hoje já não paga mais a de Lucas, o que faz com que ele possa vir só uma vez por semana. Embora Lígia tenha idade e saúde para trabalhar, ela vive à mercê do recebimento da sua aposentadoria e da pequena ajuda do pai de Lucas. Eu suponho que esta situação permite-lhe imaginar que ela vive num tempo outro, lá muito atrás como quando menina, cuidada pelos pais, como se nada tivesse mudado, o tempo não tivesse passado, não houvesse se separado.

Eu imaginava Lucas como um ser a ser constituído no tempo e pelo tempo, mas aprisionado num seio que estava congelado. Como se Lucas estivesse preso dentro da morte, gritando para sair. Grito este que nunca chegou a ser ouvido. Perdia-se num espaço oco, negro, sem fundo, sem tempo.

Em uma de suas sessões, enquanto Lucas ainda não falava, ele passou a hora sentado numa cadeira mexendo com um cavalinho em cima da mesa de um lado ao outro, num movimento repetitivo. Eu o imitava com outro cavalinho e num momento de desespero meu, eu interpretei algo como sua dificuldade em manter contato comigo e parei de mexer o cavalo. No mesmo momento, percebi o meu erro e disse a ele que essa era a sua maneira de manter o contato comigo e que era muito importante que eu não desistisse. Lucas pareceu se acalmar e voltamos a mexer os cavalos até terminar a sessão. 


\section{ARTIGOS}

Parece que as primeiras experiências de Lucas foram muito traumáticas e ele sozinho não podia manter a esperança na vida, no contato, no envolvimento. Por isso, era importante que alguém ao seu lado pudesse mantê-la por ele.

Isso não é fácil. Eu sentia muita dificuldade no não contato do Lucas, mas acreditava nas teorias de Winnicott, que dizem que em todo o ser humano há um potencial a ser desenvolvido.

Além de tudo, Lucas passou comigo duas gestações. E em cada uma delas eu pensava que iria "perdê-lo" emocionalmente e o que acontecia, curiosamente, era o oposto. Não só porque nos períodos de amamentação a minha facilidade em me identificar com ele o ajudava muito, como também, nos períodos de gestação, Lucas aflorava. Criava e desenhava histórias com mais facilidade. Na última sessão, antes da minha licença da segunda gestação, Lucas desenhou na lousa as quatro estações do ano. Começou com a que estávamos (outono) e depois desenhou o inverno.

Em seguida, desenhou o universo, os planetas e o buraco negro. Eu disse a ele que talvez ele sentisse que na nossa separação, que ocorreria no inverno, ele correria o risco de novamente ser sugado pelo buraco negro, mas que na verdade, depois do inverno, vem a primavera, estação que eu previa o meu regresso. E assim, Lucas seguiu a sessão desenhando a primavera e o verão. Parecia mais tranqüilo.

O fato de ele ficar mais "vivo" e criativo nos períodos em que eu estava grávida, penso ter a ver com o fato de ele identificar-se com o nenê.

Além disso, pareceu-me que, nesta sessão, Lucas já esboçava a noção do tempo e acho que uma gravidez pode colaborar para isso, porque ela inclui um tempo de nove meses. Mas ainda não foi esse o momento em que eu pude perceber que Lucas estava lidando com as questões do tempo tão intensamente. Isto só foi visto por mim mais tarde.

\section{A trajetória}

Desde que Lucas e eu iniciamos nosso trabalho, temos percorrido um longo caminho, com trechos muito tortuosos, sem que nunca soubéssemos aonde ele ia dar. Na verdade, eu nunca sabia, como não sei, até hoje, o que trabalhar com ele. Isso porque eu nunca sei onde ele está. Ele quase sempre entra nas sessões num profundo estado de morbidez. Eu vou lhe oferecendo estímulos porque se não o faço, ele passa a sessão inteira sentado na cadeira, olhando para o nada.

Notei que entre os vários estímulos que posso lhe oferecer, o que mais tem efeito são as histórias infantis. Mas eu trabalho no escuro, portanto, qual história contar? Qual vai lhe fazer sentido? Então eu vou tateando aleatoriamente 
$\begin{array}{lllllll}R & E & V & \text { I } & S & T & A\end{array}$

LATINOAMERICANA

DE PSICOPATOLOGIA

F U N A MEN T A L

nessa escuridão e aí percebo que dentre várias, tal história fez sentido para ele; ou porque ele fez perguntas, ou porque quer que eu repita a história, ou porque ele quer fazer um desenho sobre a história. E aí, quando eu tenho a sorte de ter acertado, as sessões seguintes transcorrem mais tranqüilas. Lucas chega "vivo" nas sessões e, por ele mesmo, vai continuando o tema de que estamos tratando, enriquecendo-o. Eu sei onde ele está, e estamos juntos. Até que chega um momento em que o tema se esgota e Lucas se perde de novo. Eu o perco. E aí, eu volto a tatear na escuridão à sua procura.

Passamos o primeiro ano de trabalho, sem que Lucas trocasse uma palavra ou um olhar comigo. As dificuldades de Lucas manter vínculos, fantasiar, simbolizar, afetavam imensamente sua separação com as pessoas.

Mesmo quando Lucas começou a falar, ele não usava a palavra "eu". Nessa época, quando eu me despedia dele, ao final de cada sessão, eu dizia "tchau, Lucas" e ele olhava-me dizendo "tchau, Lucas".

Eu ia também percebendo nesse período que eu não podia me referir a ele chamando-o de você. Ele parecia sentir-se machucado ao ouvir esse pronome e mais se esquivava de mim.

Eu tinha que referir-me a ele como Lucas e o mesmo acontecia comigo. Eu tinha que referir-me a mim como Marília.

Igual procedimento eu tinha que tomar com o espaço físico entre nós dois. Se eu me aproximasse dele, ele fugia e contorcia-se como um bichinho machucado. Eu era obrigada a manter uma certa distância e de preferência não olhar muito para ele.

Enfim, quero dizer que qualquer aproximação era sentida por ele como um grande ataque.

Portanto, suas sessões resumiam-se a ele girar a bola de isopor como se fosse um pião, mexendo o corpo para a frente e para trás, e virando-se de costas para mim a cada vez que eu the dirigia um olhar ou uma palavra.

Pensei ser necessário encontrar uma linguagem em comum, nunca antes conhecida por ele, mas descoberta por nós dois. E assim a maneira que encontrei de me aproximar dele foi, primeiramente, imitando seus gestos e ações. Sentava-me a seu lado e girava o pião, movimentando meu corpo da mesma maneira que ele. Ele começou a olhar-me e mudou o seu movimento. Começou a jogar a bola para a parede. Eu fazia o mesmo e Lucas começou a olhar-me com estranheza. Sons sem nexo começavam a sair da sua boca. Eu arrisquei jogar a bola para ele e ele aceitou, jogando-a de volta para mim. Mais ou menos dessa maneira passou-se o nosso segundo ano de trabalho.

No terceiro ano, Lucas começou a manifestar a necessidade de ouvir a minha voz. Dava risada quando lhe falava e, também repetia meus gestos. Ele repetia o que eu falava e eu repetia o que ele falava (ecolalia), usando fantoches 


\section{ARTIGOS}

para essa conversa. Ele imitava meus gestos e eu imitava os gestos dele. E assim, gradativamente, Lucas foi largando o "girar pião", os movimentos repetitivos com o corpo, a ecolalia, a imitação. Isso me fez pensar que já tínhamos encontrado uma linguagem em comum: o consenso na imitação. Era uma linguagem que transcendia as palavras, e que o ajudava a sentir-se fundido num outro corpo, que oferecia a ele a possibilidade de envolvimento.

Novos comportamentos foram surgindo. Lucas corria de um lado ao outro da sala, gritando palavras sem nexo, para mim, numa tentativa de fusão com o objeto. E depois roía as unhas a ponto de tirar pedaços das pontas dos dedos, o que demonstrava que ele era dominado por uma angústia insuportável.

Se Lucas ouvia o que não gostava, isso rompia o senso de sua continuidade física com o objeto e ele sentia-se reduzido a um "não-ser". Quando digo "ouvia o que não gostava", refiro-me a ele ouvir "de fora", "do outro", algo que the mostrasse que existia um fora e um outro, que não faziam parte dele, do seu controle, da sua ilusão. Era algo que mostrava a Lucas que há separação, antes que ele estivesse preparado para isso. A bola de isopor que ele usava como pião tinha a finalidade de bloquear o buraco da separação física, a fim de que uma ilusão de continuidade pudesse ser restabelecida e, assim, ele continuar no tempo.

Para haver ilusão de que o ser é a continuidade física do outro, é necessário que haja o outro, ali presente e atento a esse ser. E, assim, o ser pode ir se constituindo.

Acompanhando Marion Milner (1987), o setting terapêutico, com seu enquadramento temporal-espacial, funcionou como a moldura de um quadro, delimitando dentro e fora, com tempos diferentes, que hoje, numa tentativa desesperada, tentam se encontrar.

Conforme Lucas e eu íamos brincando, ele ia descobrindo limites. O brincar ligava o mundo da irrealidade subjetiva com o da realidade objetiva, fundindo as bordas, sem confundi-las.

Algumas vezes, em estados ainda mais primitivos, as sessões resumiamse em que ele ouvisse histórias que eu contava enquanto fazia outra atividade, como ler um outro livro, ou mesmo desenhar (Nessa época Lucas já estava com 9 anos). O fato de ele fazer alguma atividade ouvindo a minha voz, como um som de fundo, ajudava-o a delimitar dentro e fora, sem que ele se sentisse sozinho. Ele estava acompanhado! Por outro lado, se eu me entretinha com ele na mesma atividade, ele se sentia extremamente invadido e machucado. Ele necessitava de um acompanhamento indireto.

O setting terapêutico permitiu a Lucas viver um tempo outro, transformando-o em sensação comum, marcando uma época, criando um tempo. A análise provocou uma quebra do tempo "métrico". De um tempo "perdido", Lucas passou ao tempo redescoberto, que o fez mudar naturalmente. 
$\begin{array}{lllllll}R & E & V & \text { I } & S & T & A\end{array}$

LATINOAMERICANA

DE PSICOPATOLOGIA

FUND A M EN T A L

Comecei a perceber que Lucas já era capaz de fantasiar. Ele brincava comigo de fazer comidinha, usando guache, massinha e talheres. Lucas fazia macarrão, bife, arroz, feijão e pizza para que eu comesse. O outro, para ele, já existia.

O que acontecia nessas sessões, é que ele não queria entrar na sala de ludo se não fosse acompanhado pela mãe. Lígia por sua vez tinha muita dificuldade em aceitar essa situação. A seu entender ele tinha piorado.

Quando Lígia na sala de ludo via Lucas molhar as mãos no guache, sentia náuseas e tinha que sair correndo da sala. Isso me fazia pensar como era difícil para a sua mãe o contato, o envolvimento, a separação, e como conseqüência a impossibilidade de fantasiar.

$\mathrm{Na}$ fantasia, passado, presente e futuro não se sucedem, coexistem. $A$ capacidade de fantasiar é o que possibilita ao indivíduo flutuar entre os três tempos, entrelaçando-os pelo fio do desej. (Vivian Arab, 1996).

Mas, quando Luca podia brincar, ler e ouvir histórias, o seu mundo emocional alimentava-se de vida e a vida não existe sem o tempo. Lucas ia se preenchendo concomitantemente de vida e tempo, que não se separam.

Nesse processo de se constituir, Lucas foi passando seus anos de terapia. Quando já fazia mais ou menos cinco anos que trabalhávamos juntos, Lucas já conseguia manter comigo brincadeiras que tinham começo, meio e fim. Brincava de escola onde eu era a aluna. Montávamos casas e carros com o "Lego". Lucas desenhava pessoas, lia livros que trazia de casa, contava casos ocorridos em casa e na escola.

Hoje, aos 11 anos, Lucas fala corretamente. Seu comportamento bizarro desapareceu. Não rói mais as unhas, nem come os dedos. Lucas passa as nossas sessões lendo livros, fazendo livros, escutando histórias que conto para ele e desenhando na lousa. Dessa maneira Lucas vai transformando o mundo exterior em algo seu também, e assim vai se aproximando do mundo através das histórias. Os desenhos que ele faz acompanham também essa expectativa.

O tema das sessões gira em torno do crescimento, passagem do tempo, morte... Lucas desperta do sono do não-tempo. Ele me dizia em várias sessões: "O despertador tocou, eu acordei!"

Assim, agora ele se depara com várias modalidades temporais vividas simultaneamente. Esse é um aspecto que o angustia. Outra angústia dele diz respeito ao tempo cronológico ser irreversível e inexorável. Lucas se interessava por desenhar "a morte", copiando desenhos que a representavam em livros infantis e escutando fábulas que giram em torno do desejo e das tentativas do homem de vencer a morte, mas que acabavam sendo vencidos por ela.

Agora, todo o seu problema resume-se na indagação: - O que fazer com a eternidade do tempo interrompido? - O que fazer com um corpo tão grande em uma casa-mente tão pequena? 


\section{ARTIGOS}

Lucas desenha em suas sessões casas pequenas que abrigam um corpo grande, que mal cabe na casa. Em outras sessões, ele faz com argila um berço pequeno que abriga um bebê tão grande que mal pode aconchegar-se nele. E esse, penso ser o tema, espaços diferentes, advindos de tempos diferentes, não podem se juntar. Como uma vida do passado que não pode ser partilhada com o presente. É como se Lucas estivesse percebendo que o tempo e os eventos não são a mesma coisa; que no tempo há uma infinidade de mundos.

Lucas, na sua angústia, em uma das sessões, me disse:

- Eu vou desenhar na lousa uma casa com rodas (ria), mesa com rodas, janela com rodas (ria). Eu não vou desenhar um carro com rodas porque não tem graça, carro já tem rodas. Eu vou pôr rodas no que não tem rodas. Lucas estava aqui tentando integrar o tempo de ausência com o tempo de presença, vida, o não tempo com o tempo.

Podemos comparar sua fala à de Alan Lightman em "Sonhos de Einstein" (1966, pp. 88-89): ... num mundo onde tudo está em movimento, quando uma pessoa sai de sua casa logo cedo, ela pisa na calçada correndo. [...] Quanto mais rapidamente se movimenta uma casa, mais lentamente giram os ponteiros dos relógios dentro dela e mais tempo disponível sobra para seus ocupantes. Ocorrem-me aqui três suposições: Estaria Lucas dizendo-me que, se o tempo de sua casa mental pudesse ir mais rápido, ele alcançaria seu tempo cronológico? Seria uma tentativa de integração? Ou poderia ele estar expressando a necessidade de sentir que o ambiente se adapta ao seu ritmo?

Em seguida, descreverei uma sessão para mostrar o esforço de Lucas para integrar a noção de tempo-espaço, fundamental para as aquisições posteriores. Essa noção possibilitará a relação de objeto e tudo o que dela decorre, o que permitirá a Lucas relacionar-se de modo mais harmônico com o seu corpo e posteriormente com os objetos.

\section{Ilustração clínica}

Esta sessão ocorre numa terça-feira de manhã, no sétimo ano de sua análise. Entramos na sala. Lucas dirige-se à liusa e diz:

- Legal, lousa, eu gosto de lousa (a lousa na parede havia sido pintada recentemente). Vou desenhar o meu prédio. Ah, não é o meu prédio, é um outro, tem 15 andares. $\mathrm{O}$ sol entra aqui (apontando para a janela do prédio).

E eu resolvo acompanhá-lo dizendo:

- O sol está entrando pela janela.

Para a minha surpresa, Lucas de modo muito assustado me diz:

— Não, o sol não se mexe!

Intuitivamente senti a necessidade de acalmá-lo e lhe digo: 


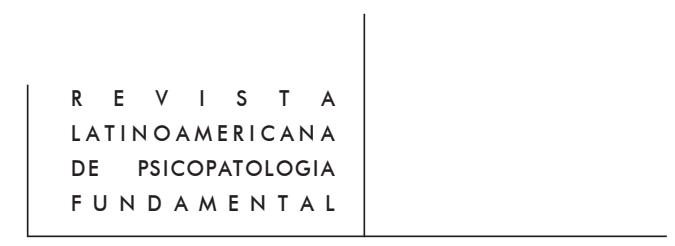

- A luz do sol entra pela janela.

Lucas se acalma e segue dizendo:

- Eu aprendi sobre os planetas, na escola. Quando é dia na Inglaterra, é noite aqui. Eu vou fazer a minha escola. A rua. Olha, eu cheguei na escola na hora $\mathrm{H}$. O que é hora $\mathrm{H}$ ?

Eu respondo:

— É a hora certa. Você me diz que não pode mais esperar, não há tempo a perder.

Lucas continua:

- Ah! A Priscila (amiga da escola) não chegou na hora $\mathrm{H}$.

Ela chegou atrasada. A minha mãe é cabeluda. O cabelo dela está ficando branco. O tempo passa. A minha mãe vai me buscar na escola.

Eu lhe digo:

- O tempo passa e você está percebendo isso. A mamãe está mais velha e parte do seu medo é de que você não tenha chegado na hora certa para ela e para a vida. Está atrasado.

Lucas me responde:

- 17:00 horas. A chuva cai. Cheguei em casa, fiz a lição, e chegou a noite (Lucas desenha a lua). Chegou o dia 07/03 (dia desta sessão).

Eu digo a ele:

- Estas coisas deixam você triste. Você está triste de ver que o tempo passa.

Lucas continua:

- Pronto, eu vou apagar o desenho da lousa. Agora eu vou fazer a história do ursinho, é da minha escola.

Eu pergunto:

- Como é a história?

Lucas responde:

- Ele tinha um relógio. Ele foi comprar uma maçã. Tinha a feira, aí ele comprou as flores e caiu. As flores caíram. As flores caíram e ele levou para a avó dele. Essa história é legal, mas eu gostei mais da história da lousa.

E eu continuo:

- A história do ursinho é a história da vida, com as várias gerações (neto, avó), e com o movimento: as flores caem, eu pego, eu ando... Você até quer viver essa história mas ela ainda o assusta.

Neste momento Lucas dirige-se à caixa e tira de lá os fantoches que foram as primeiras formas de possibilidade de comunicação verbal comigo. E como se ele realmente tivesse se dado conta da passagem do tempo entre nós, Lucas põe um fantoche numa das mãos, outro na outra e cria uma conversa entre ambos que resumia um pouco da nossa história e da sua luta. 


\section{ARTIGOS}

(mão direita) - Como vai?

(mão esquerda) - Vou bem.

(mão direita) - É legal isso.

(mão esquerda) - Foi assim que começou a terapia.

E eu pensei: foi assim que começou o tempo.

\section{Comentário}

O jogo de fantoches de fato começou a existir entre nós, dois anos depois de iniciarmos a terapia, mas para Lucas foi o marco do início da noção de tempo.

Penso também que Lucas relata nesta sessão que a história dele, por enquanto, é a de um menino triste que despenca atrasado num mundo em movimento. Isto quer dizer que partes de sua mente já entraram em movimento, quando ele relata que vai à escola, que encontra com as amigas, ou mesmo na história do ursinho que leva flores para a avó. A meu ver aqui, ele conta que sentimentos e impulsos borbulham como acontece com qualquer menino de 11 anos. Mas essas partes se contrapõem com outras ainda adormecidas e outras timidamente despertando. Vejo isto também pelos desenhos que ele fez do relato desta sessão, colocando o corpo dele maior do que o prédio e do que a escola que freqüenta.

Concluo, com esta sessão, que Lucas está num conflito. Se não há movimento, ele não cresce, não continua no tempo, nada acontece, é a morte emocional. Mas, se há movimento, este, para ele, envolve destruição, fim. Talvez em função disso ele tenha se refugiado num tempo parado.

Este fato me recorda o que aconteceu há algumas sessões quando Lucas chegou a mim, muito assustado, com um livro de ciências na mão e me perguntou mostrando a figura de um esqueleto:

- O que é esqueleto? A minha mãe me disse que é o que sobra quando a gente morre, é isso?

E então eu respondo:

- Não, esqueleto é o que nos permite ficar de pé, nos locomover, andar, sentar, correr...

Lucas fica muito aliviado e sai da sessão contando essa história para a sua mãe.

Agora eu me indago: Como fazer com que Lucas venha a poder encontrar a possibilidade de outra vivência de movimento? Como fazer Lucas ver que o esqueleto é o que sustenta a vida? Como fazer Lucas ver que movimento é um elemento da vida e não um elemento que vai levar a uma experiência catastrófica? 


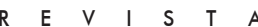

LATINOAMERICANA

DE PSICOPATOLOGIA

FUND A M EN T A L

\section{Considerações finais}

Lucas terminou essa sessão dizendo-me que emergiu de uma era sem tempo, no momento em que pôde usufruir de uma linguagem não-verbal e, principalmente, verbal para se comunicar. É como se, antes, ele nem mesmo existisse. Onde não há comunicação, não há tempo, e onde não há tempo não há ser.

Esses pacientes não estão dentro de um tempo, e esse é um dos motivos que os impede de falar, pois a fala requer uma seqüência de palavras ditas num tempo cronológico.

O tempo cronológico pode ser representado espacialmente por um rio que corre ou pelo arremesso de uma flecha. No tempo cronológico existe um antes e um depois e, ou se produz algo, ou se perde.

Afinal, o que é o tempo ? Essa é uma pergunta cuja resposta não é fácil! Santo Agostinho dizia: ... se ninguém me perguntar eu sei! Mas se quiser explicar a quem me faz a pergunta já não sei. (cf. Gondor, 1996, p. 67)

O meu interesse nessa questão é para, se possível, vislumbrar o prognóstico de um autista no que se refere ao tempo perdido.

Podemos ter várias interpretações sobre o tempo. Escolhi as que mais me agradaram.

Uma delas (Menezes, 1996) é que o tempo é aquilo que passa, que se move. Dentro do tempo que passa podemos ter dois pontos de vista: o primeiro é a idéia de sucessão, o tempo cronológico, o tempo dos relógios, o que implica o antes e o depois, passado, presente e futuro. O segundo é o tempo que pulsa, é o coração que bate, é o desejo, é a própria vida enquanto vivida. Vivida, no sentido de viver a experiência e integrá-la e, assim, abrir espaços para novas experiências. Aqui, a presença apaga o que fica ausente, para trás, e depois a consciência se move em direção à presença, e com isso quer uma presença mais forte, deixando o indivíduo na expectativa de algo mais. Aí nasce o desejo que acelera o tempo, põe-se em ação a fim de que possa vir a realizar-se. Nesse tempo, é como se passado, presente e futuro caminhassem juntos. Se nenhum empecilho ocorrer com o indivíduo e ele puder desenvolver-se normalmente dentro de suas potencialidades, esse tempo que pulsa transcorre naturalmente. Podemos dizer que esse tempo é o tempo da saúde da criação. A meu ver, esse é o tempo que Lucas vive hoje.

Outra interpretação, de Heidegger (1995), é que o tempo é a própria vida. Segundo ele, há o tempo em que se está na vida, o tempo da física, o tempo cronológico, onde o passado produz o presente, e há o tempo em que a vida é. Ou melhor, a vida é o que ainda não é, porque está sempre sendo o que ainda vai ser. A vida está por ser. Assim, o presente é um futuro que vem a ser. Um 


\section{ARTIGOS}

futuro sido, porque ela é assim, quando foi, já não é vida, já está no pretérito, converte-se em matéria petrificada, em matéria morta. A vida tão logo foi, deixa de ser. A vida é a antecipação, o afã de vir a ser, é a preocupação que faz com que o futuro seja o germe do presente. A vida, ao ir sendo, vai constituindo-se em antecipar seu ser de um modo deficiente para chegar a sê-lo de um modo eficiente. A vida é algo que corre em busca de si mesma.

Viver, portanto, é uma preocupação com um futuro que não existe. É uma angústia. Por conseguinte, a angústia é própria da vida. É o desejo de viver, de ser e de continuar sendo, para que o futuro se torne presente. Mas, o anseio de ser acompanha o temor de não ser, de deixar de ser, do nada... Por isso a vida é, por um lado, anseio de ser e, por outro, o temor do nada. Eros e Tanatos. Essa é a angústia. Essa é a esperança.

"E estava acabada a história do ano.

- Sim! - disseram os pardais. - É muito bonita. Mas esta história não está de acordo com o calendário; portanto, não vale nada." (Andersen, 1961, p. 255)

Resumos

Este trabajo se propone relatar la larga trayectoria de un niño autista en relación al establecimiento de la noción de tiempo.

Usando referenciales teóricos de Winnicott la autora busca demonstrar como el autismo es la evidencia de un "no tiempo", de un proceso que se estagnó para poder protegerse de vivencias terroríficas, vazias de cualquier sentido o significado.

Cuentos infantiles funcionaron por mucho tiempo y de diversas maneras como el único puente de contacto entre el paciente y su analista. El paciente (Lucas) pasa del uso del ritmo (el ritmo de lectura del analista) al uso del contenido para establecer el tiempo dentro de sí mismo. Tiempo de proceso, tiempo de cambio, tiempo de vida.

La posición del paciente en relación a la vida cambia. Lucas demuestra interés por su ambiente. Depende mucho de la adaptación del analista y de su habilidad para entenderlo y dar sentido a qué vivir ahora en este nuevo tiempo de descubrimiento.

This paper presents the long trajectory of an autistic child in relation to the establishment of the notion of time.

Based on the theories of Winnicott, the author seeks to demonstrate how autism is an evidence of "no time", of a process which stagnated in order to protect itself from terrifying experiences totally devoid of meaning or significance. 


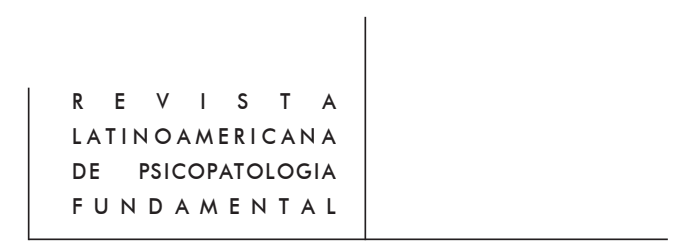

Children's stories represent for a long time and in various manners the only bridge of contact between this patient and his analyst. The patient (Lucas) switches from the use of rythm (analyst's reading rythm) to the use of content to establish time within himself. Time of process, time of change, time of life.

The patient's position regarding life changes. Lucas reveals interest toward his environment. He depends very much on the analyst's capacity to adapt and ability to understand by giving him sense to what is to be lived now during this new time of discovery.

\section{Bibliografia}

Alvarez, A. Companhia viva. Porto Alegre, Artes Médicas, 1994.

Andersen, H. C. Contos de Andersen. Vol. III. Rio de Janeiro, Globo, 1963.

Bollas, C. A sombra do objeto. Rio de Janeiro, Imago, 1992.

Heidegger, M. Ser e tempo. Petrópolis, Vozes, 1995.

Katz, C. S.; Pelbart, P. P.; Gondar Jr.; Menezes, P.; Arab, V.; Novello, M.

Temporalidade e psicanálise. Petrópolis, Vozes, 1996.

Lightmann, A. Sonhos de Einstein. São Paulo, Companhia das Letras, 1996.

MiLner, M. A loucura suprimida do homem são. Rio de Janeiro, Imago, 1987.

Tustin, F. Barreiras autísticas em pacientes neuróticos. Porto Alegre, Artes Médicas, 1990. 